\title{
Sustainable development as the basis for the tourist attractiveness of the territory
}

\author{
Natalia Pershina ${ }^{1, *}$, Marina Fedorova ${ }^{2}$, Alena Romanova $^{2}$, and Sergei Panov $^{2}$ \\ ${ }^{1}$ Tyumen State University, Volodarskogo Str. 6, 625003 Tyumen, Russia \\ ${ }^{2}$ K.G. Razumovsky Moscow State University of Technology and Management (First Cossack \\ University), Zemlyanoy Val Str. 73, 109004 Moscow, Russia
}

\begin{abstract}
The article examines the concepts of sustainable development and tourist attractiveness of territories and determines the relationship between them. Sustainable development, as well as the tourist attractiveness of the territory, are characterized mainly by economic, social and environmental characteristics. These include the turnover of tourist services, the number of rooms in hotels, the number of people employed in tourism, the ecological situation, the availability and condition of historical and cultural monuments, the level of crime, etc. The results of studies of sustainable development and tourist attractiveness of the territories of the Siberian and Ural Federal Districts of Russia are studied. Changes in rating indicators of the tourist potential of the regions of the Russian Federation are analyzed. The conclusion is made about a direct relationship between the level of sustainable development and the tourist attractiveness of territories.
\end{abstract}

\section{Introduction}

The development of world tourism is a fairly successful and integral part of the modern economy. Over the past three decades, this area has shown a steady upward trend. In 2016, the number of arrivals in the world was 1.2 billion [1]. In 2019, it grew to 1.5 billion. The Russian tourism sector has long been characterized by the presence of serious problems (the excess of outbound tourist flows over the inbound ones, the bankruptcy of tour operators, the discrepancy between the price and quality of services, etc.) [2]. The long-term successful functioning of this area is associated with the implementation of a sustainable tourism policy. The relevance of this issue for the tourism sector is constantly growing. Sustainable development is associated not only with solving the global problems of modern society but also allows to increase the commercial results of the functioning of the tourism sector. In this direction, it influences such characteristics of tourism as tourist attractiveness.

The objective of our study is to establish the relationship between the concepts of sustainable tourism development and the tourist attractiveness of territory and assess their level in the regions of Russia. The research tasks are to study the essence of the concepts of sustainable development and tourist attractiveness of territory, their interrelation and

\footnotetext{
${ }^{*}$ Corresponding author: pershina_2008@mail.ru
} 
general characteristics, research results, and ratings of sustainable development and tourist attractiveness of the regions included in the Siberian and Ural federal districts of Russia, and formulate directions for their increase. Many territories of these districts are not traditional tourist destinations but have quite rich tourist potential. The research results indicate that regions with high sustainability of the development are also characterized by high tourist attractiveness. Therefore, an objective assessment and growth of the sustainability of the development of the regions of the Siberian and Ural federal districts will increase their tourist attractiveness, demand for tourist products, and incomes of the territories.

\section{Materials and Methods}

The study is based on the concept of sustainable development, first introduced in 1987 by the International Commission on Environment. The study of the level of sustainable development of regions of the Russian Federation involved analysis of the calculation results integral indicators of economic, social, and environmental sustainability of the territories. The study of the tourist attractiveness of the regions of the Siberian and Ural Federal Districts was based on the results of the "National Tourist Rating" conducted by Rating, Center for Information Communications. The analysis of changes in the rating indicators of the regions for 2015-2019 was carried out.

A.G. Dementieva and M.I. Sokolova write that sustainable development involves a balanced solution to socio-economic problems, problems of preserving the environment and natural resource potential to meet the needs of present and future generations of people, as well as preserving the Earth's biosphere through a significant decrease in anthropogenic burden [3]. They note its inextricable relationship with the concept of social and ethical marketing. One of the main directions of sustainable development is the growth of environmental efficiency. In the 2000s, sustainable development began to be considered as one that allows meeting the needs of the current population, without depriving future generations [4].Sustainable development of tourism aims at making the programs being implemented meet the interests of residents, ensure the stable economic development of the region, and develop a set of measures to minimize environmental pollution [5].

The organization of tourism in compliance with the principles of sustainable development is the basis for increasing the tourist attractiveness of the host territory. The concept of tourist attractiveness of a region can be defined as a combination of various characteristics that increase the demand for its tourist services and products. O.A. Brel andF.Iu. Kaizer consider tourist potential as one of the components of the overall attractiveness of the territory, along with investment, migration, and business attractiveness. Tourist potential and other types affect the competitiveness of the region [6]. Tourist attractiveness is based on the tourist potential of the territory, the tourist resources available. Therefore, it is necessary to ensure their preservation and development. The concept of tourist potential is more related to the tourist supply. Creating awareness of consumers about the available tourism resources and products will turn the tourist supply into demand and contribute to an increase in tourist flow. The tourist attractiveness of the territory is related to its tourist potential; it contributes to the transformation of tourist supply into demand; often depends on the visual components of tourist objects, as well as verbal and emotional characteristics. Its main factors can include historical and cultural, natural, infrastructural, economic, and social.

As we see it, there is a close relationship between the concepts of sustainable development and the tourist attractiveness of a territory. They have common characteristics (economic, social, environmental). Sustainable development ensures long-term harmonious 
functioning of the territory, preservation of tourist resources, which undoubtedly makes it more attractive to tourists.

\section{Results and Discussion}

In 1996, the UN Commission on Sustainable Development for the first time proposed a system of indicators for sustainable development, including 132 criteria (social, economic, environmental, organizational). The World Tourism Organization has identified indicators of sustainable development related to state implementation of the concept of sustainable tourism (availability of local policy on sustainable tourism, registers of places of cultural and natural value, etc.), the impact of anthropogenic activities on the environment (use of land, energy, water, biodiversity, etc.), socio-cultural sphere (average duration of contracts for personnel, the number of registered thefts, etc.), and economy (seasonal fluctuations in employment, the average duration of overnight stays, etc.) [7].

The Russian Federation is also developing indicators for sustainable development of territories. In 2012, the WWF Russia and RIA Novosti project was implemented to develop and calculate the environmental-economic index of Russian regions. It is based on the World Bank's Net Adjusted Savings Index methodology. The gross savings of the regions were adjusted for such values as budgetary expenditures for the development of human capital, depletion of natural resources, damage from environmental pollution, etc. The value of this index is higher in the agrarian-industrial regions of Russia and rather low in rawmaterial export-oriented territories, which include, in particular, the Yamalo-Nenets and Khanty-Mansi Autonomous Okrugs. The lowest indicator was in the Altai Republic.

The Human Development Index is associated with the social aspects of sustainable development and involves the use of three sub-indices: longevity, education, and living standards. In 2013-2014, according to this indicator, Moscow, St. Petersburg, and the Tyumen region ranked first among the regions of Russia. Among the representatives of the Siberian Federal District, the index was above the average for Russia in the Tomsk Region. S. Bobylev, N. Zubarevich, S. Soloviova created an integrated index of sustainable development, which makes it possible to comprehensively consider economic, social, and environmental indicators [8].

E.A. Tretiakova and M.Iu. Osipov compared the level of socio-ecological and economic development of several Russian territories (Perm Krai, the Republic of Bashkortostan and Tatarstan, Sverdlovsk, Chelyabinsk, Nizhny Novgorod, Samara regions) for 2005-2014. The assessment involved 11 economic, 12 social, and 8 environmental indicators. Regions were analyzed using static and dynamic criteria, and building a matrix for a comprehensive assessment of sustainable development. They were generally characterized by a low level of development and balanced dynamics of indicators. Indicators of the Nizhny Novgorod, Sverdlovsk regions, and Tatarstan showed a positive trend, which shifted towards optimal sustainable development [9].

In 2014, the "Rating" Center for Information Communications and "Otdykh v Rossii" magazine conducted the National Tourism Rating. It assessed the tourist attractiveness of Russian regions by the following groups of indicators: the level of development of the tourist business; the turnover of tourist services; the popularity of the region among Russians and foreigners; tourist uniqueness; ecological "health" of the region; crime situation; development of transport and social infrastructure, provision of cultural objects; and popularity of the territory as a travel brand on the Internet. They are also related to the characteristics of sustainable tourism development.

The leaders were Krasnodar Krai, St. Petersburg, Moscow, the Republic of Crimea, and the Moscow region. Among the constituent entities of the Siberian Federal District, only the Altai Krai was in the first group (10th). The second group of the rating consisted of the 
majority of the regions of the Far East, Tyumen Region (21st), Republic of Buryatia (26th), Irkutsk region (36th), and others. The third group of participants is outsiders of the rating, who have just started to develop their tourist potential. For the most part, they are depressed (low standard of living, low incomes, undeveloped infrastructure). This group included Trans-Baikal Krai (81st), Jewish Autonomous Region (83rd), etc. The study of the annual results of this rating over time shows changes in tourist attractiveness of the regions, as well as its components related to sustainable tourism. Let us consider changes in the tourist attractiveness of the territories of the Siberian and Ural Federal Districts according to the rating data (Table 1) [10].

The Altai Krai, Irkutsk, Novosibirsk, Omsk, Kemerovo, Kurgan regions show a stable positive trend in the rating of tourist attractiveness. In general, the trend of increasing attractiveness (except for one year) is also observed in the Sverdlovsk and Chelyabinsk regions, Krasnoyarsk Krai, the Republics of Altai, and Khakassia. However, the Altai Krai, Sverdlovsk, Irkutsk, Chelyabinsk, Novosibirsk, Tyumen regions demonstrate higher tourist attractiveness than other regions. In 2019, they were included in the first group of the rating - the "golden twenty". The Omsk region, Republics of Altai and Khakassia, Krasnoyarsk Krai, Khanty-Mansi Autonomous Okrug, Kemerovo, Kurgan, Tomsk region make up the "silver" group of regions called "Strong Profi". The rest of the territories are included in the third, "bronze" rating group called "Initial level". According to the results of various studies of sustainable development, the regions included in the last groups of this rating had a lower level of sustainability than the first group.

In the Siberian Federal District, the leader in tourist attractiveness in 2019 was the Altai Krai. The region took part in the experiment to introduce a resort tax; a draft is being prepared on the creation of specially protected recreational areas, and the creation of Togul and GornayaKolyvan national parks is planned. The strengthening of sustainable tourism principles related to environmental issues has positively influenced its tourist attraction.

In the Urals Federal District, the Sverdlovsk region ranks first. The region pays much attention to people with disabilities, implements an inclusive tourism project. We tested tourist routes for such citizens ("Imperial route" - Yekaterinburg part, "Europe - Asia", "Copper capital of the Urals", "Stronghold of the state"). The duration of the tours is one to two days. Movement within the region is organized by specially equipped transport.

Table 1. Tourist attractiveness rating of the constituent entities of the Siberian and Ural Federal Districts of Russia, 2015-2019

\begin{tabular}{|c|c|c|c|c|c|}
\hline Constituent entities of the Russian Federation & 2015 & 2016 & 2017 & 2018 & 2019 \\
\hline \multicolumn{6}{|c|}{ Siberian Federal District } \\
\hline Altai Krai & 10 & 7 & 7 & 6 & 6 \\
\hline Irkutsk region & 36 & 15 & 13 & 13 & 13 \\
\hline Kemerovo region & 70 & 51 & 43 & 43 & 42 \\
\hline Krasnoyarsk Krai & 38 & 34 & 33 & 32 & 41 \\
\hline Novosibirsk region & 43 & 24 & 20 & 17 & 16 \\
\hline Omsk region & 45 & 45 & 34 & 31 & 30 \\
\hline Tomsk region & 67 & 64 & 75 & 66 & 69 \\
\hline Altai Republic & 22 & 43 & 42 & 41 & 40 \\
\hline Republic of Tyva & 85 & 82 & 82 & 82 & 82 \\
\hline Republic of Khakassia & 49 & 70 & 67 & 65 & 65 \\
\hline \multicolumn{6}{|c|}{ Ural Federal District } \\
\hline Kurgan region & 75 & 74 & 68 & 67 & 66 \\
\hline Sverdlovsk region & 24 & 17 & 10 & 7 & 10 \\
\hline Tyumen region & 21 & 36 & 22 & 19 & 19 \\
\hline Khanty-Mansi Autonomous Okrug & 51 & 47 & 52 & 42 & 56 \\
\hline Chelyabinsk region & 29 & 30 & 17 & 15 & 14 \\
\hline Yamalo-Nenets Autonomous Okrug & 62 & 63 & 63 & 78 & 77 \\
\hline
\end{tabular}


In 2017, the Tyumen region ranked fourth in Russia in terms of catering services turnover. But its "ecological" score was one of the lowest. The Omsk region demonstrates a gradual, slow increase in tourist attractiveness. It is negatively affected by the poor state of monuments and historical zones, low level of landscaping, insufficient sanitary zones, environmental problems of the atmosphere in the territory of the regional center, littering of coastal zones of water bodies and natural areas along roads and places of active tourism, low quality of roads, reduced incomes of the population, a fairly high level of inflation, unfavorable economic conditions for investments, etc.

Each region has several sustainable development problems that negatively affect its tourist attractiveness. A specific list of solutions depends on the specifics of the regions and should be provided for in long-term programs for their development. The main directions for sustainable socio-economic development of the regions should be the growth of investments in human capital, the formation of a favorable investment climate, innovative infrastructure, support for small and medium-sized businesses, reduction of differentiation in the level and quality of life of the population, increase of the provision of regional and local budgets, encouragement of interregional integration and mobility of the population [11]. An important task in ecology is the creation of a developed "ecological" industry, including the construction of treatment facilities, waste processing plants, environmental monitoring equipment, etc.

\section{Conclusion}

Thus, the sustainable development of a territory is closely related to its tourist attractiveness. The growth of the economic, social, and environmental characteristics of the regions makes them more attractive to tourists in the long term. To assess the level of sustainable development and tourist attractiveness of a territory, similar criteria are used (turnover of tourist services, the number of people employed in tourism, the ecological situation, the presence and condition of historical and cultural monuments, the level of crime, etc.) However, indicators of the level of awareness of tourists about the territory, its popularity, coverage in media and on the Internet mean much for measuring tourist attractiveness. It should be noted that the concept of tourist attractiveness, in contrast to sustainable development, is also associated with the emotional characteristics of sights and objects visited and situations experienced on the territory.

The results of studies of sustainable development and tourist attractiveness of the regions of the Siberian and Ural Federal Districts of Russia showed that there is a direct relationship between the level of their sustainable development and tourist attractiveness. Regions showing higher sustainability of development have better tourist attractiveness. These territories include the Altai Krai, the Sverdlovsk, Tyumen, Irkutsk regions. The Omsk Region, the Altai Republic, the Khanty-Mansi Autonomous Okrug are characterized by a lower tourist attractiveness and serious problems in sustainable development. To eliminate them, the regions must consider the specifics of a particular territory and provide specific measures in their growth strategies. These measures will ensure an increase in tourist attractiveness, development of the tourism sector, an increase in popularity, fame, strengthening of a positive image, and growth of regional income.

\section{References}

1. E.A. Frolova, University Bulletin, 3, 62, (2019)

2. N.V. Pershina, E.A. Panishev, L.S. Vitrenko, ANI: economics and management, 5, 299 (2016) 
3. A. G. Dementieva, M.I. Sokolova, Journal of New Economy, 5, 5 (2018)

4. D.S. Benz, Journal of New Economy, 4, 73 (2019)

5. A.G. Vasilieva, N.V. Kuznetsova, A.S. Ignatiuk, V.A. Chernenko, E.V. Bodrov, V.V. Kalinov, V.I. Golodiaeva, T.V. Rassokhina, Economic Growth in Russia: Problems and Prospects (2015)

6. O.A. Brel, F.Iu. Kaiser, Bulletin of Kemerovo State University, 3, 26 (2017)

7. E.G. Kiiakbaeva, Bulletin of Buryat State University, 1, 19 (2014)

8. S Bobylev, N. Zubarevich, S. Solovyeva,VoprosyEkonomiki, 1, 155 (2015)

9. E.A. Tretiakova, M.Iu. Osipova, Problems of forecasting, 2, 27 (2018)

10. National Tourism Rating (2019)

11. N.Iu. Sorokina, Modernization. Innovation. Development, 2, 146 (2015) 